Madrygal. Revista de Estudios Gallegos

ISSN: 1138-9664

\title{
Narrativa
}

\section{O home da miña vida}

Manuel Pereira Valcárcel

A Myriam Ameur e a Silvia Andrade

—Bo día, Bea. Que tal?

—Ai, Ana! Moi feliz. Desbordo de alegría. Coñecín o home da miña vida.

— “O home da miña vida", xa será algo menos.

—Nada menos. O home da miña vida, tal como soa.

—Vale, vale. Parabéns, logo! E como é tan rechamante personaxe?

-É adorable. Unha verdadeira delicia. Ten unha face morena de faccións perfectas, os ollos verdes e o cabelo negro, nin corto de máis nin tampouco longo en exceso. É alto, guapo e ben posto.

-Pero existen eses homes?

-Xa o creo! Ao menos hai un. E con que haxa un, xa vale. Para min é abondo.

- Sempre pensaches só en ti...

—Adán, chámase Adán.

—Adán! Non me digas que o atopaches no Paraíso.

-Non, atopeino no coche de liña. Pero pódoche dicir que onde el está, alí é onde se atopa o Paraíso.

- Claro, con tanta viaxe como fas, era visto. Un día ou outro tiña que ser...

-Estou nunha nube.

- A ver se estás enganada e non foi nun autocar onde apareceu, senón nun avión.

— Ti tómalo a broma mais non é ningunha brincadeira. É real.
—Real, como a vida mesma? Ou que é un rei?

-Real, real. Que existe, que se ve, que fala, que respira, e que inspira.

-Pois si que debe pagar a pena. Non me estraña a túa euforia.

-Dígoche máis, seméllalle a Alain Delon en A pleno sol. Reservado, clásico, seguro de si mesmo, afoutado, ambicioso, atento...

- Para, para, para. Pois si que ten virtudes.

-Non, virtudes, non. As virtudes para os santos. El ten calidades e un temperamento impecable. Unha xoia auténtica.

-Meu Deus, Alain Delon! Alain Delon foi o mito das nosas nais, que digo nais!, das nosas avoas! Ti namorácheste dun home vello.

-En absoluto. Alain Delon foi novo, e aínda o é, sempre é novo nas súas películas e na miña lembranza. resesos.

- A memoria é unha fábrica de recordos

- Eu só pretendía contarche o motivo da miña alegría e non escoitar unha sentenza...

-Non, eu non te xulgo pero eu penso que ti tes unha gaiola na cabeza.

-Non, teño os pés pousados no chan. Pero estou falando de amor. Sabes?, amor. E o amor é paixón ou non é nada. Se lle quitas a paixón e a vertixe ao amor, que che queda? Un farrapo soamente, un tempo amorfo, a imitación dunha mala novela. 
- $\mathrm{Si}$, si, o que ti queiras. Eu só pretendo dicirche que tes trinta e dous anos, non es ningunha adolescente inxenua.

- Claro que non son inxenua.

-Pois dá a impresión de que ti idealizaches un home normal. Máis guapo ca moitos, pode ser; mais unha persoa coma outra calquera. É todo.

-É todo, é todo... Ti non comprendes un corazón feliz.

-Eu comprendo ben un "corazón feliz" pero o que non comprendo é unha cabeza liviá e caprichosa.

-É o home da miña vida, asegúrocho! Non é ningún antollo de mociña léveda.

-Pois, mira, xa que o dis, si, quizais teñas fermento de máis no teu corazón.

- O corazón tense que mover, constantemente. Non pode parar.

- O que che quero dicir é que talvez che sobre un algo de alborozo.
-Non sobra, non. O que sucede é que ti non es nada romántica. Ti es unha analista fría que rexeita os soños.

-Eu non refugo os soños, non. Pero eu soño exclusivamente cando durmo. Durante o día eu non soño, penso.

—Que vida a túa! Triste, sen emoción, sen fervenzas, sen risco.

-Non, non te compadezas de min. Estou ben como estou, non boto nada en falla.

- Se non se voa non se pode tocar o ceo!

-Tamén voan os foguetes, pero chegados a un punto estoupan e caen.

-Pero mentres soben, arden...

- Ben, fai como queiras. É a túa vida. Sigue a voar. Pero despois non chores, cando te precipites á terra.

- Tranquila, sei caer e tamén me sei erguer.

- Mira, unha cousiña, xa para rematar: Adán é o home da túa vida, fica claro; e ti, ti es a muller da súa vida?

-Evidentemente. Eu son a muller da súa vida para todos os homes da miña vida. 